\title{
rDNA-based characterization of a new binucleate Rhizoctonia spp. causing root rot on kale in Brazil
}

\author{
Eiko E. Kuramae - Alexandre L. Buzeto • \\ Andreia K. Nakatani • Nilton L. Souza
}

Received: 8 March 2006/Accepted: 10 May 2007/Published online: 8 June 2007

(C) KNPV 2007

\begin{abstract}
In this paper we present the first report of the occurrence of a binucleate Rhizoctonia spp. causing hypocotyl and root rot in kale in Brazil. Rhizoctonia spp. were isolated from kale (Brassica oleracea var. acephala) with symptoms of hypocotyl and root rot. The isolates, characterized as binucleate Rhizoctonia spp., did not show an anastomosis reaction with any of the binucleate Rhizoctonia spp. testers used. The pathogenicity of the isolates was tested under greenhouse conditions; all isolates were pathogenic and showed different symptom severities on kale. The ITS-5.8S rDNA sequences of kale isolates and 50 testers ( 25 binucleate Rhizoctonia spp. and 25 Rhizoctonia solani) were compared in order to characterize the genetic identity of Rhizoctonia spp. infecting kale. The kale isolates showed genetic identities ranging from 99.3 to $99.8 \%$ and were phylogenetically closely related to CAG 7 (AF354084), with identities of 98.5 and $98.7 \%$. It is suggested that the binucleate Rhizoctonia spp. caus-
\end{abstract}

E. E. Kuramae ( $\bowtie)$

CBS - Fungal Biodiversity Centre, Uppsalalaan 8, 3584

CT Utrecht, The Netherlands

e-mail: kuramae@nioo.knaw.nl

E. E. Kuramae

Netherlands Institute of Ecology (NIOO-KNAW), Boterhoeksestraat 48, 6666 ZG Heteren, The Netherlands

A. L. Buzeto - A. K. Nakatani - N. L. Souza

UNESP, Faculdade de Ciências Agronômicas, CP 237,

18603-970 Botucatu, SP, Brazil ing hypocotyl and root rot on kale Brazil comprises a new AG not yet described.

Keywords Anastomosis group $\cdot$ ITS1 $\cdot$ ITS2 $\cdot 5.8 \mathrm{~S}$ rDNA

Rhizoctonia species are basidiomycete fungi associated with important agricultural and horticultural crops grown all over the world. These fungi are able to colonize and/or infect seeds, roots, leaves, stems and fruits of many crops. Rhizoctonia spp. comprise an important multinucleate species complex represented by $R$. solani and several others which are either mononucleates or binucleates. Up to now, there are 14 anastomosis groups (AG) of $R$. solani described: AG-1 to AG-13 and AG-BI (Carling 2000). Binucleate Rhizoctonia species are grouped either in seven AGs (CAG1 to CAG7) in the USA (Burpee et al. 1980) or 19 AGs (AGA to AGS) around the world (Ogoshi 1987).

While most of the $R$. solani AGs are recognized as important plant pathogens, the binucleate Rhizoctonia species are mostly considered as mycorrhizal or having a role as biocontrol agents (Burpee and Goulty 1984; Cardoso and Echandi 1987a, b; Herr 1988; Escanbde and Echandi 1991; Harris and Adkins 1999). Thus, only a few of the known binucleate Rhizoctonia spp. AG are pathogenic. Non-pathogenic binucleate Rhizoctonia spp. are commonly found in soil organic matter or in plant debris. In a few Brazilian fields sampled, they were mostly associated with beans, peanuts (Ceresini and Souza 1997) and 
soybeans (Fenille et al. 2002) primarily infected by $R$. solani AG $4 \mathrm{HG}-\mathrm{I}$ or AG $2.2 \mathrm{IIIB}$, causing damping-off and root rot symptoms. Most of these binucleate Rhizoctonia spp. were non-pathogenic and were considered to have potential for biocontrol (Harris 2000). Pathogenic binucleate Rhizoctonia spp. isolates belonging to AG $\mathrm{E}$ have been observed associated with soybean in the USA (Ploetz et al. 1985) and Indonesia (Naito et al. 1993). A few other binucleate Rhizoctonia spp. isolates were pathogenic to potato roots (Carling and Leiner 1990) and yacon (Fenille et al. 2005). Distinct AGs of $R$. solani have already been identified causing disease on different vegetable crops in Brazil (Bolkan and Ribeiro 1985; Kuramae et al. 2003). However, there are no reports on the occurrence of pathogenic binucleate Rhizoctonia causing disease on vegetable crops in Brazil. Particularly on kale, a Rhizoctonia-like disease has been observed causing outbreaks in São Paulo State vegetable-growing areas. Hypotcotyl and root rot symptoms have been observed on kale.

Considering the local importance of this Rhizoctonia-like disease for kale production, the objective of this study was to characterize the Rhizoctonia spp. isolates infecting kale by determining their nuclear condition, hyphal anastomosis grouping, virulence and genetic identity with other Rhizoctonia spp. based on sequencing analysis of the ITS-5.8S rDNA region. Our hypothesis was that a binucleate Rhizoctonia spp. is the primary agent of a hypotcotyl and root rot disease detected on kale.

The isolates were collected from kale (Brassica oleracea var. acephala) cultivated in Lençois Paulista, SP, Brazil, with hypocotyl and root rot symptoms. Small sections (0.5-0.7 cm long) were cut from the edge of an advancing lesion on each diseased root sample. These samples were surface-sterilised by immersion in $70 \%$ ethanol for $30 \mathrm{~s}, 2 \%$ sodium hypochlorite for $30 \mathrm{~s}$, washed in sterile distilled water (SDW) and placed directly on Ko and Hora medium (1971). The nuclear condition and hyphal anastomosis grouping of the isolates were determined using the procedure of Ceresini et al. (1996). Hyphal cells were examined microscopically at 200 and 400x and nuclei were counted in 20 cells per isolate. Kale binucleate Rhizoctonia spp. isolates were paired against the AG testers (AG A, AG Ba, AG Bb, AG Bo, AG C, AG D, AG F, AG G, AG O, AG P and AG Q) available in our laboratory. Hyphal anastomosis was observed at $400 \times$ magnification using light microscopy after staining the vegetative cells with a $0.03 \%$ safranin-O aqueous solution and a $3 \% \mathrm{KOH}$ aqueous solution. All isolates of Rhizoctonia spp. obtained were binucleate and did not show anastomosis reactions with any of the binucleate Rhizoctonia spp. testers used. However, in the absence of a few AG testers of binucleate Rhizoctonia spp. being not available in our laboratory (CAG 1, CAG 3, CAG 4, CAG 5, CAG 6, CAG 7, AG L, AG T and AG U), a phylogenetic approach was used for characterizing the unknown kale isolates. We based this approach on the comparative analysis of sequences of the ITS5.8S rDNA region from all the AGs of binucleate Rhizoctonia spp. as well as the Rhizoctonia solani available and the unknown kale isolates. The

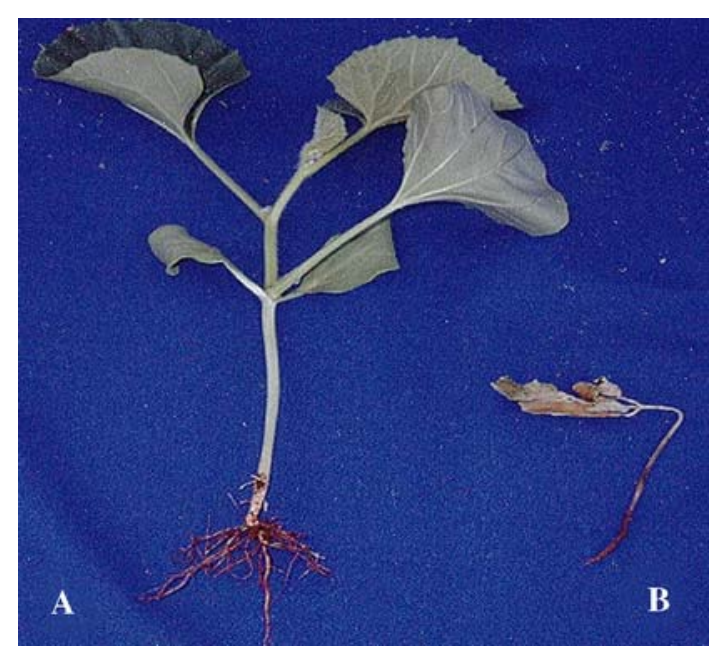

Fig. 1 (A) is the control. (B) Pathogenicity of isolate CO4 of binucleate Rhizoctonia spp. to kale after 20 days of inoculation

Table 1 Virulence of binucleate Rhizoctonia spp. on kale 20 days after inoculation

\begin{tabular}{ll}
\hline Isolate & Disease severity index ${ }^{1,2}$ \\
\hline $\mathrm{CO} 4$ & $2.00 \mathrm{a}$ \\
$\mathrm{CO} 2$ & $1.92 \mathrm{ab}$ \\
$\mathrm{CO} 1$ & $1.66 \mathrm{~b}$ \\
$\mathrm{CO} 3$ & $1.66 \mathrm{~b}$ \\
$\mathrm{Control}$ & $0.00 \mathrm{c}$ \\
\hline
\end{tabular}

${ }^{1}$ Disease severity scored as $0=$ no symptoms, $1=$ hypocotyl and cotyledon symptoms, $2=$ pre-emergence damping-off, 3 = post-emergence damping-off

2 Means followed by the same letter within a column are not significantly different by the Tukey test $(P=0.05)$ 
sequences of the unavailable AGs were obtained from the GenBank. This approach provided us with some information about the placement of the unknown kale isolates among the AGs described for binucleate Rhizoctonia spp. worldwide. The use of a molecular tool is not currently accepted as a replacement criterion for the hyphal anastomosis characterization of AGs of Rhizoctonia spp. However, in certain instances the sequencing of the ITS-5.8S rDNA region has been used to separate subgroups of $R$. solani when anastomosis itself cannot separate them (Kuninaga et al. 1997).

The pathogenicity of the isolates was tested under greenhouse conditions at $25 \pm 2^{\circ} \mathrm{C}$ using the substrate and inoculum preparation recommended by Fenille and Souza (1999). A completely randomized block design with five replications was used. After trans- ferring the inoculum to the substrate, thirty seeds of kale cv. Portuguesa were sown per pot. Disease severity was assessed, 20 days after inoculation, using the scale described by Chung et al. (1988) and the fungus was re-isolated. All isolates caused hypocotyl and root rot symptoms on kale (Fig. 1) with different symptom severities. $\mathrm{CO} 4$ and $\mathrm{CO} 2$ isolates were the most virulent isolates $(P=0.05)$ (Table 1).

To characterize the genetic identity of Rhizoctonia species infecting kale with other binucleate Rhizoctonia spp., four kale isolates (CO1, CO2, CO3, CO4) were compared with 12 binucleate Rhizoctonia spp. testers available in our laboratory (AG A, AG Ba, AG Bb, AG Bo, AG C, AG D, AG F, AG G, AG O, AG P and $A G Q$ ), and 39 testers (13 binucleate Rhizoctonia spp. and $25 R$. solani) publicly available sequences.

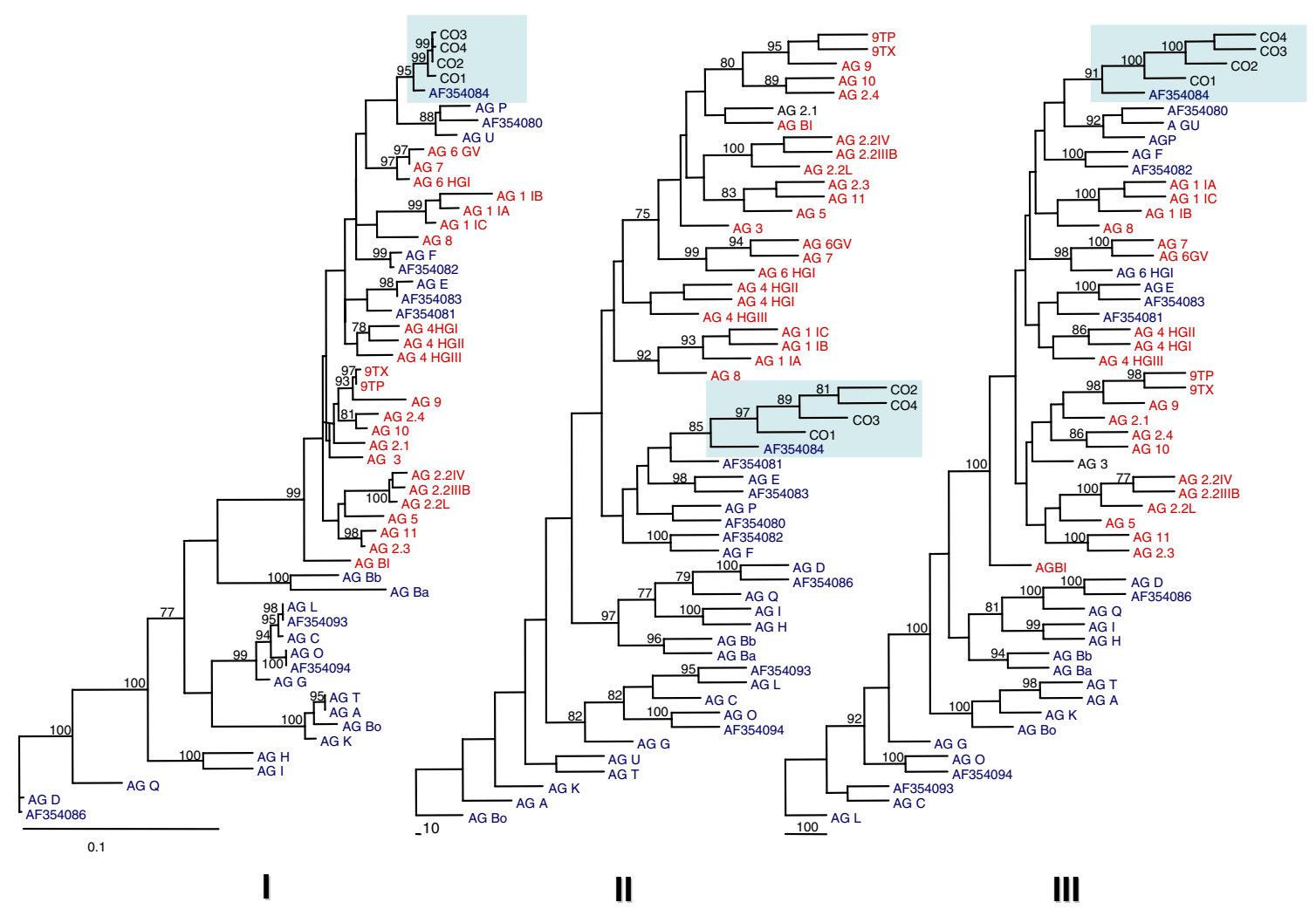

Fig. 2 Phylogenetic trees constructed by Maximum Likelihood (I), Maximum Parsimony (II), and Neighbour-Joining (III) methods illustrating the phylogenetic relationship of four isolates from kale $(\mathrm{CO} 1, \mathrm{CO} 2, \mathrm{CO} 3, \mathrm{CO} 4)$ and 50 testers [26 binucleate Rhizoctonia spp. (blue colour), and $24 R$. solani (red colour)]. The sequences of AF354086 (CAG1), AF354080 (CAG3), AF354081 (CAG4), AF354082 (CAG5), AF354083
(CAG6), AF354084 (CAG7), AF354093 (AGL), AF354094 (AGO), AB196663 (AGT) and AB196664 (AGU) are from GenBank. The numbers at branches indicate $\%$ of 100 bootstrap replications. Only branches with $>75 \%$ are shown. The ITS1-5.8S-ITS2 sequences of Rhizoctonia binucleate spp. of kale were deposited at GenBank: CO1 (DQ279021), CO2 (DQ301760), CO3 (DQ279022) and CO4 (DQ301761) 
Table 2 Similarity (\%) between Rhizoctonia testers (Rhizoctonia binucleate species and R. solani) and isolates of kale (CO1, CO2, $\mathrm{CO} 3, \mathrm{CO} 4)$

\begin{tabular}{|c|c|c|c|c|c|}
\hline Tester number & Isolate tester & $\mathrm{CO} 1$ & $\mathrm{CO} 2$ & $\mathrm{CO} 3$ & $\mathrm{CO} 4$ \\
\hline AF354086 (CAG1) & Rhizoctonia binucleate & 87.2 & 87.5 & 87.4 & 87.4 \\
\hline AG D & Rhizoctonia binucleate & 87.2 & 87.5 & 87.4 & 87.4 \\
\hline AG Q & Rhizoctonia binucleate & 88.3 & 87.9 & 87.7 & 87.7 \\
\hline $\mathrm{AG} \mathrm{Bb}$ & Rhizoctonia binucleate & 88.0 & 88.4 & 88.2 & 88.2 \\
\hline AG I & Rhizoctonia binucleate & 88.2 & 88.4 & 88.2 & 88.2 \\
\hline $\mathrm{AG} \mathrm{Ba}$ & Rhizoctonia binucleate & 89.1 & 89.0 & 88.8 & 88.8 \\
\hline AG H & Rhizoctonia binucleate & 89.4 & 89.6 & 89.4 & 89.4 \\
\hline $\mathrm{AG} \mathrm{T}$ & Rhizoctonia binucleate & 91.2 & 90.8 & 90.6 & 90.6 \\
\hline AG $\mathrm{K}$ & Rhizoctonia binucleate & 91.0 & 90.8 & 90.6 & 90.6 \\
\hline AG A & Rhizoctonia binucleate & 91.3 & 90.9 & 90.7 & 90.7 \\
\hline AG Bo & Rhizoctonia binucleate & 91.3 & 91.4 & 91.3 & 91.3 \\
\hline $\mathrm{AG} \mathrm{G}$ & Rhizoctonia binucleate & 91.4 & 91.7 & 91.6 & 91.6 \\
\hline $\mathrm{AG} \mathrm{C}$ & Rhizoctonia binucleate & 92.1 & 92.4 & 92.2 & 92.2 \\
\hline AF354094 (AGO) & Rhizoctonia binucleate & 92.2 & 92.4 & 92.2 & 92.2 \\
\hline $\mathrm{AG} \mathrm{O}$ & Rhizoctonia binucleate & 92.2 & 92.4 & 92.2 & 92.2 \\
\hline AF354093 (AGL) & Rhizoctonia binucleate & 92.3 & 92.7 & 92.5 & 92.5 \\
\hline AG L & Rhizoctonia binucleate & 92.3 & 92.7 & 92.5 & 92.5 \\
\hline AG 2.2IIIB & Rhizoctonia solani & 92.7 & 92.7 & 92.5 & 92.5 \\
\hline AG 2.2IV & Rhizoctonia solani & 92.7 & 92.7 & 92.5 & 92.5 \\
\hline AG 2-2LP & Rhizoctonia solani & 93.2 & 93.2 & 93.0 & 93.0 \\
\hline AG 9 & Rhizoctonia solani & 93.0 & 93.2 & 93.0 & 93.0 \\
\hline AG $1 \mathrm{IB}$ & Rhizoctonia solani & 93.4 & 93.4 & 93.2 & 93.2 \\
\hline AG 2.4 & Rhizoctonia solani & 94.0 & 93.8 & 93.6 & 93.6 \\
\hline AG 1 IA & Rhizoctonia solani & 93.8 & 94.0 & 93.8 & 93.8 \\
\hline AG BI & Rhizoctonia solani & 94.4 & 94.0 & 93.8 & 93.8 \\
\hline AG 3 & Rhizoctonia solani & 94.7 & 94.5 & 94.3 & 94.3 \\
\hline AG $1 \mathrm{IC}$ & Rhizoctonia solani & 94.5 & 94.7 & 94.5 & 94.5 \\
\hline AG 11 & Rhizoctonia solani & 94.8 & 94.6 & 94.5 & 94.5 \\
\hline AG 5 & Rhizoctonia solani & 94.3 & 94.6 & 94.5 & 94.5 \\
\hline AG 4 HGI & Rhizoctonia solani & 94.6 & 94.7 & 94.6 & 94.6 \\
\hline AG 4 HGII & Rhizoctonia solani & 94.7 & 94.9 & 94.7 & 94.7 \\
\hline AG F & Rhizoctonia solani & 94.9 & 94.9 & 94.7 & 94.7 \\
\hline AG 10 & Rhizoctonia solani & 94.7 & 94.9 & 94.7 & 94.7 \\
\hline 9TX & Rhizoctonia solani & 94.7 & 94.9 & 94.7 & 94.7 \\
\hline AG 2.3 & Rhizoctonia solani & 95.2 & 95.0 & 94.8 & 94.8 \\
\hline AG 4 HGIII & Rhizoctonia solani & 95.1 & 95.1 & 94.9 & 94.9 \\
\hline 9TP & Rhizoctonia solani & 94.9 & 95.0 & 94.9 & 94.9 \\
\hline AF354082 (CAG5) & Rhizoctonia binucleate & 95.3 & 95.3 & 95.1 & 95.1 \\
\hline AG 2.1 & Rhizoctonia solani & 95.1 & 95.2 & 95.1 & 95.1 \\
\hline AG 8 & Rhizoctonia solani & 95.3 & 95.4 & 95.2 & 95.2 \\
\hline AG $6 \mathrm{GV}$ & Rhizoctonia solani & 95.2 & 95.4 & 95.2 & 95.2 \\
\hline AF354080 (CAG3) & Rhizoctonia binucleate & 95.6 & 95.6 & 95.4 & 95.4 \\
\hline AG E & Rhizoctonia binucleate & 95.6 & 95.6 & 95.5 & 95.5 \\
\hline AF354083 (CAG6) & Rhizoctonia binucleate & 95.6 & 95.8 & 95.6 & 95.6 \\
\hline
\end{tabular}


Table 2 continued

\begin{tabular}{|c|c|c|c|c|c|}
\hline Tester number & Isolate tester & $\mathrm{CO} 1$ & $\mathrm{CO} 2$ & $\mathrm{CO} 3$ & $\mathrm{CO} 4$ \\
\hline AG U & Rhizoctonia binucleate & 95.9 & 95.9 & 95.7 & 95.7 \\
\hline AF354081 (CAG4) & Rhizoctonia binucleate & 95.8 & 96.0 & 95.8 & 95.8 \\
\hline AG 7 & Rhizoctonia solani & 96.0 & 96.1 & 96.0 & 96.0 \\
\hline AG 6 HGI & Rhizoctonia solani & 96.0 & 96.1 & 96.0 & 96.0 \\
\hline AG P & Rhizoctonia binucleate & 96.4 & 96.4 & 96.2 & 96.2 \\
\hline AF354084 (CAG7) & Rhizoctonia binucleate & 98.5 & 98.7 & 98.5 & 98.5 \\
\hline $\mathrm{CO} 1$ & & 100 & 99.5 & 99.3 & 99.3 \\
\hline $\mathrm{CO} 3$ & & 99.3 & 99.8 & 100 & 99.6 \\
\hline $\mathrm{CO} 2$ & & 99.5 & 100 & 99.8 & 99.8 \\
\hline $\mathrm{CO} 4$ & & 99.3 & 99.8 & 99.6 & 100 \\
\hline
\end{tabular}

Total genomic DNA was extracted from the isolates using the methodology of Kuramae-Izioka (1997). The ITS4/ITS5 primer set (White et al. 1990) was used for PCR amplification of nuclear ITS1 and ITS2 regions and the 5.8S rRNA gene.

Each PCR product was purified using MicroSpin S-400 HR columns (Amersham Pharmacia), according to the instructions of the manufacturer, and sequenced using $10 \mathrm{ng}$ of PCR product and $1 \mu \mathrm{M}$ each of the ITS2, ITS3, ITS4 or ITS5 primers following the protocol supplied with the Amersham Premix Terminator (Amersham Pharmacia). Sequencing was performed using a PE Applied Biosystems Model 377 DNA Sequencer. The four sequenced fragments generated from each isolate were assembled using Phred/Phrap (Ewing et al. 1998) and Consed (Gordon et al. 1998). All consensus bases were of high quality with a Phred value $>20$. The consensus sequence for each isolate was trimmed in order to have the ITS1-5.8S-ITS2 sequence analyzed. First, the sequences were aligned using the computer software package CLUSTAL X (Thompson et al. 1997). The alignment parameters were gap opening $=10$, gap extention $=0.20$, delay divergent sequences $=30 \%$, DNA transition weight $=0.50$. Second, poorly aligned positions and divergent regions in the alignment were removed by using Gblocks 0.91b (Castresana 2000). The threshold parameters used were: minimum number of sequences for a conserved position $=50 \%$ of the number of sequences +1 , minimum number of sequences for a flank position $=85 \%$ of the number of sequences, maximum number of contiguous non- conserved positions $=8$, minimum length of a block $=10$. Thirty, distances (\% divergence) between all pairs of sequences from the multiple alignment were calculated. The trees showing the phylogenetic relatedness between isolates and AG testers (Rhizoctonia binucleate and $R$. solani) were constructed using three different phylogenetic methods: maximum likelihood (PHYML) (Guindon and Gascuel 2003), maximum parsimony (MP), and neighbourjoining (NJ). For PHYML, the nucleotide model was HKY85 (Hasegawa et al. 1985), the transition/ transversion ratio was 4 , and the Gamma distribution parameter was 1.0. MP and NJ analyses were done using PROTPARS (heuristic search with characters equally weighted) and PROTDIST (Kimura formula) from Phylip (Felsenstein 1996), respectively. Nonparametric bootstrap support for MP and NJ was calculated from 100 resampling rounds.

All phylogenetic methods applied, viz. PHYML, $\mathrm{MP}$, and NJ resulted in trees supporting the same phylogenetic position of the four kale isolates (Fig. 2). The kale isolates showed genetic identities ranging from 99.3 to $99.8 \%$ (Table 2) between them, even though they were collected from plants in the same field. The kale isolates were phylogenetically closely related to CAG 7 (AF354084) (Fig. 2), with identities of 98.5 and $98.7 \%$ (Table 2). The number of nucleotide differences among kale isolates and CAG 7 was higher at the ITS1 region (10 nucleotides) than at the ITS2 region (5 nucleotides). It is suggested that the binucleate Rhizoctonia spp. causing hypocotyl and root rot on kale Brazil comprises a new AG not yet described. 
Acknowledgements We thank Dr. S. Hyakumachi (Faculty of Agriculture, Gifu University, Gifu, Japan) for supplying tester strains of binucleate Rhizoctonia spp. Scholarship granted by Fundação de Amparo à Pesquisa do Estado de São Paulo, FAPESP to the second author is gratefully acknowledged.

\section{References}

Bolkan, H. A., \& Ribeiro, W. R. C. (1985). Anastomosis groups and pathogenicity of Rhizoctonia solani isolates from Brazil. Plant Disease, 69, 599-601.

Burpee, L. L., Sanders, P. L., Cole, H. Jr., \& Sherwood, R. T. (1980). Anastomosis groups among isolates of Ceratobasidium cornigerum (Bourd.) Rogers and related fungi. Mycologia, 72, 689-701.

Burpee, L. L., \& Gouty, L. G. (1984). Supression of brown patch disease of creeping bentgrass by isolates of nonpathogenic Rhizoctonia spp. Phytopathology, 74, 692694.

Cardoso, J. E., \& Echandi, E. (1987a). Biological control of Rhizoctonia root rot of snap bean with binucleate Rhizoctonia - like fungi. Plant Disease, 71, 167-170.

Cardoso, J. E., \& Echandi, E. (1987b). Nature of protection of bean seedlings from Rhizoctonia root rot by a binucleate Rhizoctonia - like fungus. Phytopathology, 77, 15481551.

Carling, D. E. (2000). Anastomosis groups and subsets of anastomosis groups of Rhizoctonia solani. In: Proceedings of the $3^{\text {rd }}$. International Symposium on Rhizoctonia. 2000, Taichung, Taiwan, 14.

Carling, D. E., \& Leiner, R. H. (1990). Virulence of isolates of Rhizoctonia solani AG-3 collected from potato plant organs and soil. Plant Disease, 74, 901-9033.

Castresana, J. (2000). Selection of conserved blocks from multiple alignments for their use in phylogenetic analysis. Molecular Biology and Evolution, 17, 540-552.

Ceresini, P. C., \& Souza, N. L. (1997). Associação de Rhizoctonia spp. binucleadas e de $R$. solani Kühn GA 4 HGI e GA 2-2 IIIB ao feijoeiro (Phaseolus vulgaris L.) no estado de São Paulo. Summa Phytopathologica, 23, 14-24.

Ceresini, P. C., Fenille, R. C., \& Souza, N. L. (1996). Associação de Rhizoctonia spp. binucleadas e de $R$. solani Kühn GA 4 HGI à vagens de amendoinzeiro (Arachis hypogaea) no Estado de São Paulo. Summa Phytopathologica, 22, 145-155 (in Portuguese).

Chung, Y. R., Hoitink, H. A. H., \& Lipps, P. E. (1988). Interactions between organic-matter decomposition level and soilbone disease severity. Agriculture, Ecosystems and Environment, 24, 183-193.

Escanbde, A. R., \& Echandi, E. (1991). Protection of potato from Rhizoctonia canker with binucleate Rhizoctonia fungi. Plant Pathology, 40, 197-202.

Ewing, B., Hillier, L., Wendl, M., \& Green, P. (1998). Basecalling of automated sequencer traces using phred. I. Accuracy assessment. Genome Research, 8, 175-185.

Felsenstein, J. (1996). Inferring phylogenies from protein sequences by parsimony, distance, and likelihood methods. Methods in Enzymology, 266, 418-427.
Fenille, R. C., \& Souza, N. L. (1999). Efeitos de materiais orgânicos e da umidade do solo na patogenicidade de Rhizoctonia solani Kühn GA-4 HGI ao feijoeiro. Pesq Agrop Bras, 34,1959-1967.

Fenille, R. C., Souza, N. L., \& Kuramae, E. E. (2002). Characterization of Rhizoctonia solani associated with soybean in Brazil. European Journal of Plant Pathology, 108, 783-792.

Fenille, R. C., Ciampi, M. B., Souza, N. L., Nakatani, A. K., \& Kuramae, E. E. (2005). Binucleate Rhizoctonia sp. AG G causing root rot in yacon (Smallanthus sonchifolius) in Brazil. Plant Pathology, 54, 325-330.

Gordon, D., Abajian, C., \& Green, P. (1998). Consed: A graphical tool for sequence finishing. Genome Research, 8, 195-202.

Guindon, S., \& Gascuel, O. (2003). A simple, fast, and accurate algorithm to estimate large phylogenies by maximum likelihood. Systematic Biology, 52, 696-704.

Harris, A. R., \& Adkins, P. G. (1999). Versatility of fungal and bacterial isolates for biological control of damping-off disease caused by Rhizoctonia solani and Pythium spp. Biological Control, 15, 10-18.

Harris, A. R. (2000). Solid formulations of binucleate Rhizoctonia isolates suppress Rhizoctonia solani and Pythium ultimum in potting medium. Microbiological Research, 154, 333-337.

Hasegawa, M., Kishino, H., \& Yano, T. (1985). Dating of the human-ape splitting by a molecular clock of mitochondrial DNA. Journal of Molecular Evolution, 22, 160-174.

Herr, L. J. (1988). Biocontrol of Rhizoctonia crown and root of sugar beet by binucleate Rhizoctonia spp. and Laetisaria arvalis. Annals of Applied Biology, 113, 107-118.

Ko, W., \& Hora, K. F. (1971). A selective medium for the quantitative determination of Rhizoctonia solani in soil. Phytopathology, 61, 707-710.

Kuninaga, S., Natsuaki, T., Takeuchi, T., \& Yokozawa, R. (1997). Sequence variation of the rDNA regions within and between anastomosis groups in Rhizoctonia solani. Current Genetics, 32, 237-243.

Kuramae-Izioka, E. E. (1997). A rapid, easy and high yield protocol for total genomic DNA isolation from Colletotrichum gloeosporioides and Fusarium oxysporum for RAPD. Revista Unimar, 19, 683-689.

Kuramae, E. E., Buzeto, A. L., Ciampi, M. B., \& Souza, N. L. (2003). Identification of Rhizoctonia solani AG 1-IB in lettuce, AG 4 HG-I in tomato and melon, and AG 4 HGIII in broccoli and spinach, in Brazil. European Journal of Plant Pathology, 109, 391-395.

Naito, S., Mohamad, D., Nasution, A., \& Purwanti, H. (1993). Soil-borne diseases and ecology of pathogens on soybean roots in Indonesia. Japan Agricultural Research Quarterly, 26, 247-253.

Ogoshi, A. (1987). Ecology and pathogenicity of anastomosis and intraspecific groups of Rhizoctonia solani Kühn. Annual Review of Phytopathology, 25, 125-143.

Ploetz, R. C., Mitchell, D. J., \& Gallaher, R. N. (1985). Characterization and pathogenicity of Rhizoctonia species from a reduced-tillage experiment multicropped to rye and soybean in Florida. Phytopathology, 75, 833-839.

Thompson, J. D., Gibson, T. J., Plewniak, F., Jeanmougin, F., \& Higgins, D. G. (1997). The ClustalX windows inter- 
face: flexible strategies for multiple sequence alignment aided by quality analysis tools. Nucleic Acids Research, 25, 4876-4882.

White, T. J., Bruns, T., Lee, S., \& Taylor, J. W. (1990). Amplification and direct sequencing of fungal ribosomal
RNA genes for phylogenetics. In M. A. Innis, D. H. Gelfand, J. J. Sninsky, T. J. White (Eds.), PCR Protocols: A Guide to Methods and Applications (pp. 315-322). San Diego, CA, USA: Academic Press. 